\title{
Critical Skills of IS Professionals: A Model for Curriculum Development
}

\author{
Cheryl L. Noll and Marilyn Wilkins \\ Information Systems, Eastern IIlinois University, Charleston, IL USA
}

ctcIn@eiu.edu ctmlw@eiu.edu

\section{Executive Summary}

In the rapidly changing field of Information Systems, educational programs must be continually reevaluated and revised. This can be a daunting task. To make this process more manageable and to create programs that more accurately reflect the demands of the marketplace, a curriculum revision process is presented. As part of the curriculum revision process, a study was conducted to determine the expected skills and knowledge required for Information Systems professionals in three general staffing groups: programmers, analysts, and end-user support. A survey instrument was developed asking respondents to rate the importance of each knowledge/skill area three years from now for each of the staffing groups. The results show that Information Systems knowledge relating to the entire organization and overall business knowledge will be important with less emphasis on advanced IS applications. The so-called 'soft skills' such as teamwork and collaboration, planning and leading projects, presentation delivery, and writing skills will be critical for success in the Information Systems profession. More importance will be placed on web-based languages rather than more traditional languages such as COBOL. Based on the analysis, a skills matrix is presented that can be used as a foundation for developing courses. This paper also describes a curriculum development model that can be used as a guide for curriculum revision.

Keywords: curriculum development, information systems skills, information systems knowledge, programming skills, analyst skills, end-user support skills

\section{Introduction}

Revolutionary changes are occurring across the United States and throughout the world in information systems technology. "The number of workers in the computer and software industries has almost tripled in the past decade." (Freeman and Aspray, 1999. p. 35.) According to the Bureau of Labor Statistics projections for the period 2000-2010, of the 10 fastest growing occupations, computer-related occupations occupy eight of the top ten positions: software applications engineers, support specialists, systems software engineers, network and systems administrators, network systems and data communications analysts, desktop publishers, database administrators, and systems analysts. (BLS, Table 3b). Computer

Material published as part of this journal, either on-line or in print, is copyrighted by the publisher of the Journal of Information Technology Education. Permission to make digital or paper copy of part or all of these works for personal or classroom use is granted without fee provided that the copies are not made or distributed for profit or commercial advantage AND that copies 1) bear this notice in full and 2) give the full citation on the first page. It is permissible to abstract these works so long as credit is given. To copy in all other cases or to republish or to post on a server or to redistribute to lists requires specific permission and payment of a fee. Contact Editor@JITE.org to request redistribution nermission. and data processing services is projected as the industry with the fastest wage and salary employment growth (BLS, Table 3a).

Every sector of the American economy employs information systems workers in every geographic region of the country. This projected growth in information systems related occupations is reflected in the need for well-educated IS professionals. Currently, the demand for trained profes- 
sionals far exceeds qualified applicants. The State of Illinois Citizens Agenda (1999) specifically calls for an increase in the number of graduates with skills and knowledge needed to meet new or emerging occupational demand. The State of Illinois Board of Higher Education (IBHE) Workforce Issues Paper (1999) calls for the number of baccalaureate computer and information science graduates from public universities to be doubled by 2006. Information Technology Association of America (2000) reports that "... employers will create a demand in this country for roughly 1.6 million IT workers this year. With demand for appropriately skilled people far exceeding supply, half of these positions--843,328--will likely go unfilled. In a total U.S. IT workforce of 10 million, that shortfall means one job in every dozen will be vacant." (Information Technology Association of America, I1, 2000). These circumstances create an atmosphere whereby Information Systems programs need to be reevaluated and changed to meet the demand. Educators have the overwhelming responsibility of designing a curriculum that prepares future IS professionals for this dynamic field.

Researchers have struggled with the issue of implementing curriculum models in various ways. Kim, Shim, and Yoon (1999) asked IS practitioners and educators to rate the importance of key IS issues. They found that practitioners perceive managerial and organizational issues as more important than educators do. They also indicate that educators consider emerging issues such as e-commerce, more important than practitioners do. They recommended that educators and practitioners should have a shared vision of key IS issues and collaborate on curriculum development. Lightfoot (1999) describes the dilemma of IS curriculum design as a problem of balance between the fundamentals of IS and the current "fad" applications. He suggests that students and businesses (employers) have short-term perspectives, while educators have a long-term perspective; legislators (public) are somewhere in between. He recommends modifying curriculum to satisfy the goals of the stakeholders.

Srinivasan, Guan, and Wright (1999) describe a process of developing a new curriculum working with corporate partners. They also suggest using the corporate partners as "clinical": faculty to help teach the courses. Maier, Clark, and Remington (1998) reviewed the content of job advertisements over a 15-year period to explore the changes in the MIS job market and found a growing diversity in the MIS job market. Hingorani and Sankar (1995) surveyed perceptions of graduates' skills and compared the results with skills required in industry. They found that students were aware of the needs of industry. They also made specific recommendations for their specific program.

The foundation of the curricula revision process is to review the literature related to expected workplace skills and knowledge for IS professionals. In a project which studied the impact of changes in the IS profession on the skills and knowledge requirements on future IS professionals, Lee, Trauth \& Farwell (1995) report that the industry will demand IS professionals who can lead organizational IS activities and possess not only technological skills, but also business operations, management, and interpersonal skills. Lee, Trauth and Farwell project a more decentralized IS organization with an end-user-focused business orientation. They recommend that a generic curriculum meeting the needs of all future IS professionals is obsolete, and that different IS curricula must be developed to meet different IS careers paths.

In 1996, Maglitta, writing in Computerworld, reported that IS programs are struggling to keep up to date with the latest technologies and changes. Interviews with academicians and IS managers indicated new graduates lack the needed technical, business, industry, and soft skills needed in today's business world. Few graduates are trained in hot technologies such as telecommunications and relational databases--or even exposed to them. Even fewer are taught project management, communication, documentation, and team skills. Fewer still learn about specific industries or new areas such as electronic commerce and business process re-engineering. In a survey of IS programs in the United States, Gill \& Hu (1998) report that the most popular programming languages were $\mathrm{C} / \mathrm{C}++, \mathrm{SQL}$ and $\mathrm{COBOL}$, and that the dominant operating systems are Windows/OS2 and Unix. They suggested that there has been a transition 


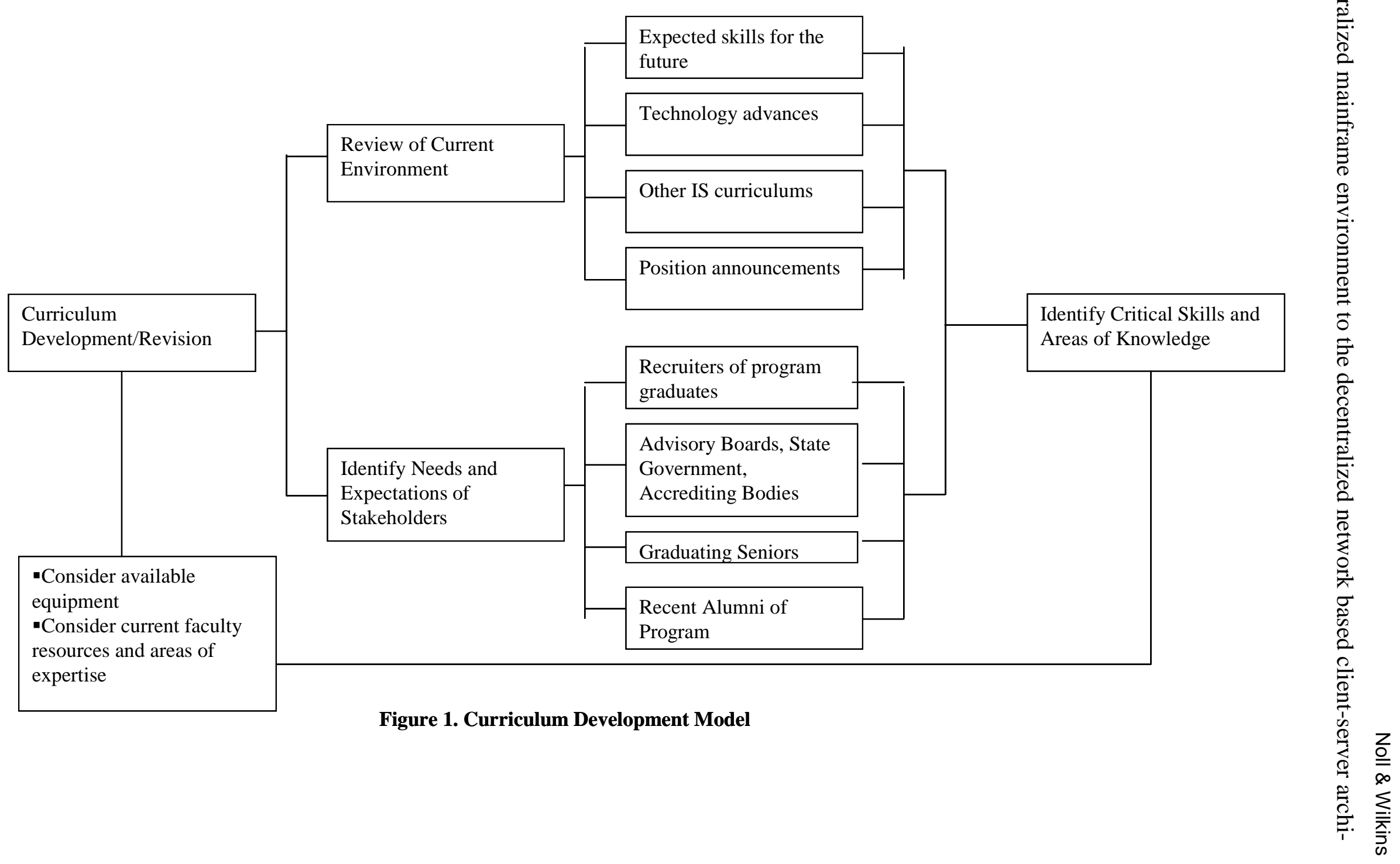


Other studies have stressed the impact of the Internet on IS skills and curricula, (Chaudhury \& Rao, 1999), the importance of client/server technologies (Chaudhury \& Rao, 1997; Alexander, 1997) and the importance of interpersonal and communications skills, (Young \& Lee, 1997). Gonzenbach (1998) surveyed businesses and recommended placing the most emphasis on telecommunications, operating systems, systems analysis and design, networks and business communications.

While the reported need for an increased supply of information systems workers is clearly documented, the identification of specific skills required for the variety of positions in IS is not as clear. While several model curricula exist, none of them can be easily applied to individual university programs. Curricula changes require assessment of several factors including needs of business recruiting at the University, current curricula, students, resources, and faculty skills. Figure 1 suggests a model that can be used for curriculum development. The model includes assessing the needs of stakeholders and reviewing the current environment to assist in identifying critical skills. Once these critical skills are identified, they can then be organized into a structure that takes into consideration the available resources including faculty and equipment.

In this paper, a study is reported that was conducted to determine what employers perceived to be the most critical areas of knowledge and skills for IS professionals within the next three years. In particular, these questions were addressed:

- What will be the important skills and knowledge required for future employees in Information Systems?

- What programming languages will be considered most important?

- Are there different levels of importance placed on skills and knowledge depending on job classification or staffing position?

\section{Research Methods}

Based on extensive review of prior research, job announcements and advertisements, and IS literature, a questionnaire was developed. The questionnaire was fashioned after the research done by Lee, Trauth \& Farwell (1999). The questions consisted of a listing of IS knowledge, programming, platforms/operating systems/applications, networking and database software, business functional knowledge, and interpersonal and management skills. The questionnaire was designed to elicit the importance of those skills to various staffing groups. Experts from local industries were asked to complete the questionnaire and evaluate it for clarity and understanding. The revised questionnaire was mailed to all of the 380 companies who recruit all majors at a Midwestern University of approximately 10,000 students plus 100 additional companies from the Best 100 Places to Work in IT (Computerworld, 1999). After a three-week time period, a follow-up letter was mailed. Sixty-seven questionnaires were returned. Of those returned, 60 were usable giving a $13 \%$ response rate. While the response rate may seem low, those who did respond were the companies that routinely recruit information systems majors from this University.

Respondents were asked to rate the importance of each skill area three years from now for each of three staffing groups: programmers, analysts, and end-user support personnel. Programmers were defined as people doing software development and maintenance. Analysts were defined as people responsible for the planning, analysis, design and implementation of business applications. End-user support people were defined as IS staff providing computing support to users.

\section{Results}

Respondents were asked to indicate their job title, industry type and organization size. Of the 60 respondents, 18 were CIOs, managers, or directors of IS; 9 were senior general managers; 16 were middle 
mangers or supervisors (IS or general); 11 were recruiters or human resources personnel; and 6 were technical specialists, analysts, or programmers. Those companies responding represented computer consulting and services; finance, insurance, real estate; government; health care; retail; services; and other miscellaneous industries. The companies ranged in size from 20 employees to 100,000 employees with about half having fewer than 1,000 employees. Even though these respondents may seem dissimilar in type and size, they represent the companies who routinely recruit at this University.

The results were analyzed using SPSS for the PC. Factor Analysis (with varimax rotation) indicated five factors with eigenvalues of more than one that accounted for $66 \%$ of the variance of the data. Eight items describing knowledge of business functions were combined and labeled Business Knowledge. Five items describing specialized information systems were combined and labeled Advanced IS Applications. Six items describing systems related to end-users were labeled User Support. Three items describing programming, software and database were labeled Programming. The last factor consisting of three items related to IS systems planning was labeled Systems Planning. See Table 1 for the individual items making up each factor.

\begin{tabular}{|c|c|}
\hline Table 1. Critical Skills Factors & \\
\hline Critical Skills Categories & $\begin{array}{l}\text { Principal } \\
\text { Components }\end{array}$ \\
\hline \multicolumn{2}{|l|}{ Business Knowledge (Factor 1) } \\
\hline Knowledge of business functions & .820 \\
\hline $\begin{array}{l}\text { Ability to interpret business problems and develop appropriate techni- } \\
\text { cal solutions }\end{array}$ & .794 \\
\hline Ability to understand the business environment & .850 \\
\hline Knowledge of specific industry (retail, manufacturing, financial, etc.) & .650 \\
\hline Ability to work collaboratively in a team project environment & .610 \\
\hline $\begin{array}{l}\text { Ability to develop and deliver effective, informative and persuasive } \\
\text { presentations }\end{array}$ & .692 \\
\hline Ability to plan, organize, and lead projects & .569 \\
\hline $\begin{array}{l}\text { Ability to plan, organize, and write technical manuals, documentation, } \\
\text { and reports }\end{array}$ & .539 \\
\hline \multicolumn{2}{|l|}{ Advanced IS Applications (Factor 2) } \\
\hline Electronic commerce & .577 \\
\hline Decision support systems \& group decision support & .735 \\
\hline Expert systems/AI/neural networks & .751 \\
\hline Knowledge management systems & .668 \\
\hline Executive support systems & .661 \\
\hline \multicolumn{2}{|l|}{ User Support (Factor 3) } \\
\hline End-user computing support & .861 \\
\hline Help desk/information center & .901 \\
\hline
\end{tabular}


Critical Skills of IS Professionals

\begin{tabular}{|c|c|c|}
\hline & Training/education & .573 \\
\hline & Telecommunications/networks & .551 \\
\hline & $\begin{array}{l}\text { Ability to work closely with users and maintain positive user or client } \\
\text { relationship }\end{array}$ & .525 \\
\hline \multicolumn{3}{|c|}{ Programming (Factor 4) } \\
\hline & Software applications development \& selection & .785 \\
\hline & Database modeling \& development & .718 \\
\hline & Programming/CASE tools & .509 \\
\hline \multicolumn{3}{|c|}{ Systems Planning (Factor 5) } \\
\hline & Hardware acquisition (evaluation and selection) & .622 \\
\hline & Systems analysis & .590 \\
\hline & Information systems planning, management \& evaluation & .522 \\
\hline & Information access \& security & .668 \\
\hline
\end{tabular}

The General Linear Model was used to determine if there were any differences in the importance of these factors among the three staffing areas according to the business respondents. The Least Significance Difference test was used to determine where these differences were as shown in Table 2. The means for the Factors are shown in Table 3.

\begin{tabular}{|c|c|c|c|c|}
\hline \multicolumn{5}{|c|}{$\begin{array}{l}\text { Table 2. Multiple Comparisons } \\
\text { Least Significant Differences }\end{array}$} \\
\hline Dependent Variable & (I)Case & (J)Case & Mean Difference (I-J) & Significance \\
\hline \multirow[t]{6}{*}{ Business Knowledge } & 1.00 & 2.00 & $-.5469 *$ & .000 \\
\hline & & 3.00 & .1352 & .391 \\
\hline & 2.00 & 1.00 & $.5469 *$ & .000 \\
\hline & & 3.00 & $.6821 *$ & .000 \\
\hline & 3.00 & 1.00 & -.1352 & .391 \\
\hline & & 2.00 & $-.6821 *$ & .000 \\
\hline \multirow[t]{6}{*}{ Advanced IS Applications } & 1.00 & 2.00 & -.1393 & .478 \\
\hline & & 3.00 & .3242 & .095 \\
\hline & 2.00 & 1.00 & .1393 & .478 \\
\hline & & 3.00 & $.4634^{*}$ & .018 \\
\hline & 3.00 & 1.00 & -.3242 & .095 \\
\hline & & 2.00 & $-.4634 *$ & .018 \\
\hline \multirow[t]{2}{*}{ User Support } & 1.00 & 2.00 & -.2929 & .065 \\
\hline & & 3.00 & $-1.0871 *$ & .000 \\
\hline
\end{tabular}




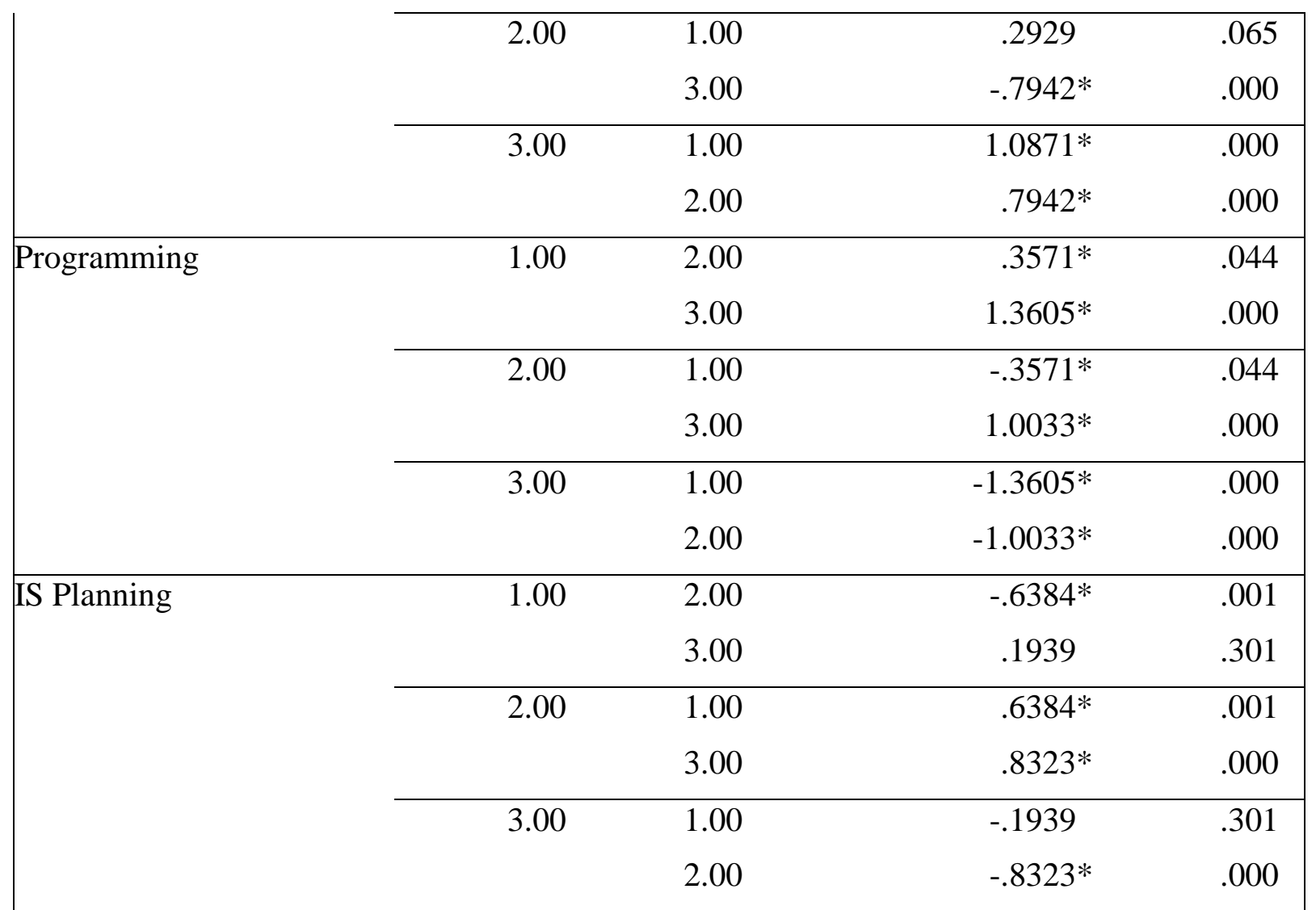

Based on observed means.

1=Programmer, 2=Analyst, 3=User Support

* The mean difference is significant at the .05 level.

\begin{tabular}{|c|c|c|c|c|}
\hline \multicolumn{5}{|c|}{$\begin{array}{l}\text { Table 3. Means of Critical Skills Factors } \\
\text { Business Respondents }\end{array}$} \\
\hline & \multicolumn{4}{|c|}{ Means } \\
\hline Factors & All & 1 & 2 & 3 \\
\hline Business Knowledge (Factor 1) & 4.08 & 3.95 & 4.50 & 3.82 \\
\hline Advanced IS Applications (Factor 2) & 3.11 & 3.18 & 3.31 & 2.85 \\
\hline User Support (Factor 3) & 3.82 & 3.35 & 3.64 & 4.44 \\
\hline Programming (Factor 4) & 3.50 & 4.09 & 3.73 & 2.73 \\
\hline Systems Planning (Factor 5) & 3.29 & 3.15 & 3.79 & 2.95 \\
\hline
\end{tabular}

1= Programming, 2= Analysts, 3= User Support

Business Knowledge was significantly different between the analysts staffing group and each of the other two groups. Means reveal that Business Knowledge $(\mathrm{M}=4.50)$ was most important for the analyst staffing group; however, the means for each of the three groups were over 3.8.

Advanced IS Applications was significantly different between the analyst staffing group and the user support staffing group. Means show that Advanced IS Applications $(\mathrm{M}=3.31)$ is most important for the analyst staffing group and least important for the user support staffing group $(\mathrm{M}=2.85)$. The means for each of the three groups were less than 3.31 . 
User Support was significantly different between the user support staffing group and the each of the other two staffing areas. Means reveal the obvious, that User Support is most important for the user support staffing group ( $M=4.44)$. It was somewhat important for the analyst staffing group ( $M=3.64)$ and least important for the programming staffing group $(\mathrm{M}=3.35)$.

Programming was significantly different among all three staffing groups. Means reveal that it is most important for the programming staffing area $(\mathrm{M}=4.09)$ and least important for the user support staffing area $(\mathrm{M}=2.73)$.

Systems Planning was significantly different between the analyst staffing group and the other two groups, with means revealing that it is most important for the analyst staffing group $(\mathrm{M}=3.79)$, somewhat important for the programming staffing group $(\mathrm{M}=3.29)$ and least important for the user support staffing group ( $\mathrm{M}=2.95)$.

Table 4 shows the means for the importance of various programming languages for the programming staffing area. New programming languages are expected to be more important than traditional languages such as COBOL

Table 4. Languages Considered Important to the Programmer Staffing Group

\begin{tabular}{|l|l|l|}
\hline Language & Mean & SD \\
\hline Web-related languages (Perl, CGI, Java Script, HTML) & 4.26 & 1.19 \\
\hline SQL & 4.16 & 1.14 \\
\hline Java & 4.13 & 1.16 \\
\hline Visual Basic & 4.06 & 1.13 \\
\hline C++ & 3.76 & 1.30 \\
\hline C & 3.25 & 1.33 \\
\hline COBOL & 3.16 & 1.53 \\
\hline
\end{tabular}

\section{Results of Companion Alumni Survey}

An on-line survey was also conducted with students who graduated from the program within the last five years (Wilkins and Graves, 2000). They were asked to rate the importance of each skill to their job. Each of the respondents was asked to classify his/her job as one the three staffing groups. Of 337 graduates contacted, 56 responded for a response rate of $16.6 \%$. The means of their evaluations were calculated using the factors determined by the business respondents. Results of the perceived importance of each of the critical skills according to the alumni respondents are reported in Table 5. 
Table 5. Means of Critical Skills Factors Alumni Respondents

\begin{tabular}{|l|c|c|c|l|}
\hline \multicolumn{1}{|c|}{ Factors } & \multicolumn{5}{c|}{ Means } \\
\hline & All & $\mathbf{1}$ & $\mathbf{2}$ & $\mathbf{3}$ \\
\hline Business Knowledge (Factor 1) & 4.17 & 4.04 & 4.57 & 3.90 \\
\hline Advanced IS Applications (Factor 2) & 3.21 & 3.13 & 3.54 & 2.97 \\
\hline User Support (Factor 3) & 3.91 & 3.40 & 3.86 & 4.47 \\
\hline Programming (Factor 4) & 3.67 & 4.19 & 3.91 & 2.91 \\
\hline Systems Planning (Factor 5) & 3.55 & 3.33 & 4.08 & 3.24 \\
\hline
\end{tabular}

1= Programming, $2=$ Analysts, $3=$ User Support

The alumni rated the importance of the skill areas similarly to the business respondents. Business Knowledge $(\mathrm{M}=4.57)$ was most important for the analyst staffing group; however, the means for each of the three groups were over 3.9, confirming the business respondents' evaluation. Advanced IS Applications $(\mathrm{M}=3.54)$ is most important for the analyst staffing group and least important for the user support staffing group $(\mathrm{M}=2.97)$. The means for each of the three groups were less than 3.54. User Support is most important for the user support staffing group $(\mathrm{M}=4.47)$. It was somewhat important for the analyst staffing group $(M=3.86)$ and least important for the programming staffing group $(M=3.4)$. Programming was most important for the programming staffing area $(\mathrm{M}=4.19)$ and least important for the user support staffing area $(M=2.91)$. Systems Planning is most important for the analyst staffing group $(\mathrm{M}=4.08)$, somewhat important for the programming staffing group $(\mathrm{M}=3.33)$, and less important for the user support staffing group $(\mathrm{M}=3.24)$.

\section{Proposed Model Curriculum Matrix}

The five factors-Business Knowledge, Advanced IS Applications, Programming, User Support, and Analyst - could be used to develop a matrix for an IS curriculum which might include a common core, three concentrations, and electives as illustrated in Table 6.

Based on the level of importance attached to the means of each skill factor, they were placed in the matrix as either required or elective areas. Since the critical skill factor Business Knowledge was considered important for all three staffing groups, this skill comprises the core of the IS program. The concentrations include the three staffing groups of programming, analyst, and user support. Since the critical skill factor Programming was considered most important for the programming group and somewhat important for the analyst group, this skill factor would be required for the programming concentration and offered as an elective for the analyst concentration. The critical skill factor User Support was considered most important for the user support group and somewhat important for the analyst group; therefore, this skill area would be required for the user support concentration and offered as a possible elective for the analyst concentration. The critical skill factor Advanced IS Applications was not considered as important for any of the staffing groups; therefore, this skill could be offered periodically in the program as a special topic. 
Table 6. Proposed Information Systems Curriculum Matrix

\section{Core Skills-Required for All Concentrations}

- Knowledge of business functional areas

- Ability to interpret business problems and develop appropriate technical solution

- Ability to understand the business environment

- Knowledge of specific industry

- Ability to work collaboratively in a team project environment

- Ability to develop and deliver effective, informative and persuasive presentations

- Ability to plan, organize, and lead projects

- Ability to plan, organize, and write technical manuals, documentation, and reports
Elective Areas for All Concentrations-

Offered as Special Topics

- E-Commerce

- DSS-GSS

- Expert Systems

- Knowledge Management Systems

- Executive Support Systems

\begin{tabular}{|c|c|c|}
\hline \multicolumn{3}{|c|}{ Concentrations } \\
\hline $\begin{array}{l}\text { Programming- } \\
\text { Required Areas } \\
\text { - } \quad \text { Database modeling \& de- } \\
\text { velopment } \\
\text { - Software applications de- } \\
\text { velopment \& selection } \\
\text { - CASE tools } \\
\text { - Languages: C++; Java; web } \\
\text { related }\end{array}$ & $\begin{array}{l}\text { Analyst- } \\
\text { Required Areas } \\
\text { - } \quad \text { Hardware acquisition } \\
\text { (evaluation and selection) } \\
\text { - } \quad \text { Systems analysis } \\
\text { - } \quad \text { IS planning, management \& } \\
\text { evaluation } \\
\text { - Information access \& secu- } \\
\text { rity }\end{array}$ & $\begin{array}{l}\text { User Support- } \\
\text { Required Areas } \\
\text { - } \quad \text { Telecommunications/ net- } \\
\text { works } \\
\text { - } \quad \text { End-user computing support } \\
\text { - } \quad \text { Help desk/information cen- } \\
\text { ter } \\
\text { - Training/education }\end{array}$ \\
\hline $\begin{array}{l}\text { Elective Areas } \\
\text { - } \quad \text { Hardware acquisition } \\
\text { (evaluation and selection) } \\
\text { - Systems analysis } \\
\text { - IS planning, management \& } \\
\text { evaluation } \\
\text { - Information access \& secu- } \\
\text { rity }\end{array}$ & $\begin{array}{l}\text { Elective Areas } \\
\text { - } \quad \text { Database modeling \& de- } \\
\text { velopment } \\
\text { - } \quad \text { Software applications de- } \\
\text { velopment \& selection } \\
\text { - } \quad \text { CASE tools } \\
\text { - } \quad \text { Languages: C++; Java web } \\
\text { related } \\
\text { - Telecommunica- } \\
\text { tions/networks } \\
\text { - } \quad \text { End-user computing support } \\
\text { - Help desk/information cen- } \\
\text { ter } \\
\text { - Training/education }\end{array}$ & $\begin{array}{l}\text { Elective Areas } \\
\text { - } \quad \text { Hardware acquisition } \\
\text { (evaluation and selection) } \\
\text { - } \quad \text { Systems analysis } \\
\text { - } \quad \text { IS planning, management \& } \\
\text { evaluation } \\
\text { - Information access \& secu- } \\
\text { rity }\end{array}$ \\
\hline
\end{tabular}

\section{Conclusions}

This research verifies the trend identified by Lee, Trauth, and Farwell, (1995) that IS jobs are becoming diversified and that generic IS curriculum will not meet all the needs for all IS jobs. Curricula could be developed consisting of separate distinctive concentrations that target the diverse job market.

For programmers, database, programming, and CASE tools will continue to be important, but less emphasis is being placed on specific advanced IS applications such as DSS, ESS, and Knowledge Management Systems. More importance is placed on web-based languages, (Perl, JavaScript, and the like) SQL, and Java, with less emphasis placed on structured programming languages like COBOL. This con152 
firms prior researchers results (Gill \& Hu, 1998; Chaudhury \& Rao, 1997; and Alexander, 1997). Often the career track to analyst requires some prior experience as a programmer. Therefore, coverage of the relationship of IS to the business organizational environment should be included in the curriculum to better prepare students to advance to systems analysts jobs.

The so-called "soft skills" have typically been important to the user support staffing area; however, this research shows that these skills are becoming increasingly important to all areas of IS confirming research by Young and Lee (1997) and Lee, Traugh, and Farwell (1995). The "soft skills" that should be integrated into the curriculum include writing, working in a team environment, delivering presentations, managing projects, and developing interpersonal relationships.

From the critical skills identified in the curriculum matrix, the course and program requirements would be developed. After the courses and program are developed, stakeholders should be given the opportunity to review them and make additional recommendations. Those responsible for developing the IS curriculum should ensure that the critical skill areas are included in course offerings. Electives and special topic courses would be based on such factors as faculty expertise, student need, and specific employment demands. As part of the ongoing process of curriculum development and program improvement, enrollment data, recruiting trends, and placement data should be continually monitored.

\section{References}

Alexander, S., (Nov 24, 1997), "Where will the opportunities be?" Info World. v. 19 n. 47, p. 99.

Bureau of Labor Statistics, (2001, December 3), “Table 3b. The 10 fastest growing occupations, 2998-2008.” Retrieved January 3, 2002 from the World Wide Web: http://stats.bls.gov/news.releast/ecopro.t06.htm

Bureau of Labor Statistics, (2001, December 3), "Table 3a, The 10 industries with the fastest wage and salary employment growth, 1998-2008." Retrieved January 7, 2002 from the World Wide Web: http://stats.bls.gov/news.release/ecopro.t03.htm.

Chaudhury, A. and H. R. Rao, (Fall 1997), "Introducing client/server technologies in information systems curricula." The DATABASE for Advances in Information Systems. v. 38, n. 4, pp. 20-32.

Chaudhury, A. and H. R. Rao, (1999), "Impact of Internet on information systems skills requirement." Proceedings of 1999 IRMA International Conference, Hershey, PA, pp. 732-736.

Freeman, P. and W. Aspray, (1999), "The supply of information technology workers in the United States." Computing Research Association, Washington, D. C.

Gill, T. G., and Q. Hu, (1998), "Information systems education in the USA.” Education and Information Technologies, v. 3, pp. 199-137.

Gonzenbach, N. M, (Spring 1998), "Developing an information systems curriculum with input from business and industry." Office Systems Research Journal, pp. 9-14.

Hingorani, K. K. and C. S. Sankar, (Summer 1995), "Entry level MIS jobs: Industry expectations versus academic preparation.” Journal of Computer Information Systems, pp. 18-27.

Information Technology Association of America, (2000), "Executive Summary- Bridging the Tap: Information Technology Skills for a New Millennium.” Retrieved March 12, 2001 from the World Wide Web: http://www.itaa.org/workforce/studies/hw00execsumm.htm.

Kim, Y., S. J. Shim, and K. P. Yoon, (May 1999), "Bridging the gap between practitioner-educator perceptions of key IS issues for effective implementation of IS curriculum.” Proceedings of 1999 IRMA International Conference, Hershey, PA. pp. 513-518.

Lee, Denis M. S., E. Trauth, and D. Farwell, (September 1999), "Critical skills and knowledge requirements of IS professionals: A joint academic/industry investigation.” MIS Quarterly, v. 19, pp. 313-340.

Lightfoot, J. M., (Sept./Oct., 1999), "Fads versus fundamentals: The dilemma for information systems curriculum design." Journal of Education for Business, v. 75, n. 1, pp. 43-50.

Maglitta, J., (Feb. 19, 1996), “IS schools: Need improvement,” Computerworld, v. 30 n. 8, pp. 78-83. 


\section{Critical Skills of IS Professionals}

Maier, J. L., W. J. Clark, and W. S. Remington, Jr., (Fall 1998), “A longitudinal study of the management information systems (MIS) job market.” Journal of Computer Information Systems. v. 39, n. 1, pp. 37-41.

Srinivasan, S., J. Guan, and A. L. Wright, (Spring 1999), “A new CIS curriculum design approach for the $21^{\text {st }}$ century.” Journal of Computer Information Systems. v. 39, n. 3, pp. 99-106.

State of Illinois, (February2, 1999), “A citizens' agenda for Illinois higher education, the Illinois commitment: Partnerships, opportunities, and excellence.” Springfield, IL.

State of Illinois Board of Higher Education, (October 1999), "Information technology workforce issues paper."

"The 100 best places to work in IT", (June 28, 1999), Supplement to Computerworld, pp. 12-21.

Wilkins, M. and P. Graves (March 2000), "Collecting Assessment and Revision Data: An On-line Survey of IS Graduates," Proceedings of Information Systems and Quantitative Methods, Midwest Business Administration Association, Chicago, IL, pp. 46-50.

Young, D. and S. Lee, (Winter 1997), "Corporate hiring criteria for IS graduates," Information Systems Management, v. 14, pp. 47-53.

\section{Biographies}

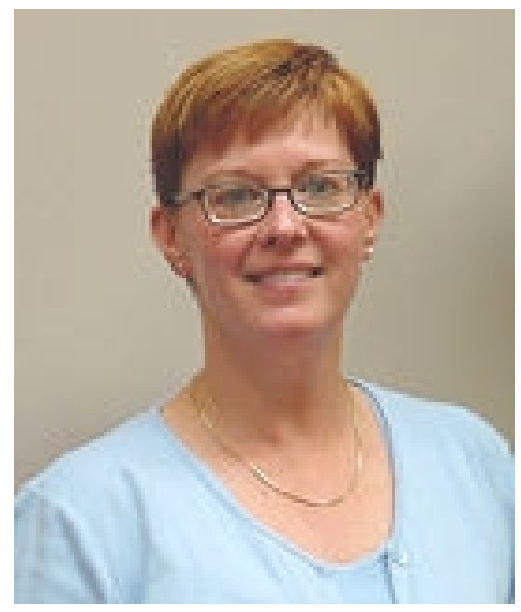

Cheryl L. Noll is Professor in the School of Business at Eastern Illinois University, where she has taught for 11 years. She teaches management communication courses in the Computer Information Systems program and the MBA program. She is currently the Director of Graduate Business Programs in the School of Business. Her research interests include technical writing skills in the information systems profession and organizational communication.

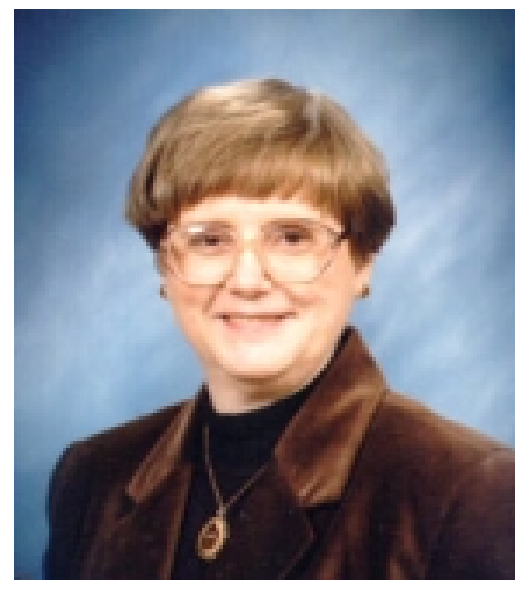

Marilyn Wilkins is Professor of Computer Information Systems in the School of Business at Eastern Illinois University, where she has taught for 18 years. She teaches courses in undergraduate courses in microcomputer applications and web page design and the MIS course in the MBA program. Her research interests include electronic communications, IS curriculum and end-user computing. 